\title{
No.46
}

SEPTIEMBRE DE 2018

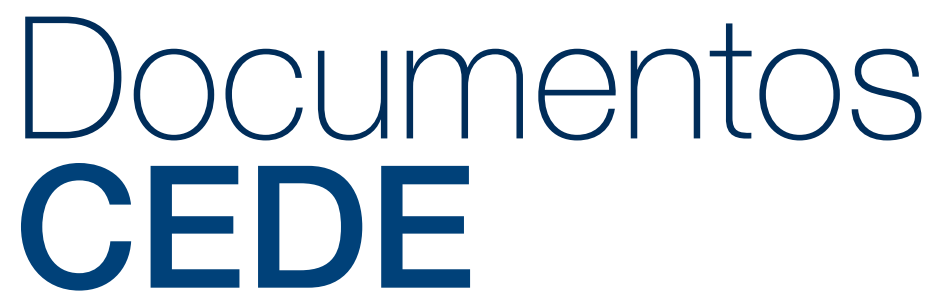

ISSN 1657-7191 Edición electrónica.

Performance, diversity and national identity Evidence from association football

\section{Jorge Tovar}




\section{CEDE}

D1)

Facultad de Economía

Serie Documentos Cede, 2018-46

ISSN 1657-7191 Edición electrónica.

Septiembre 2018

(C) 2018, Universidad de los Andes, Facultad de Economía, CEDE. Calle 19A No. 1 - 37 Este, Bloque W.

Bogotá, D. C., Colombia Teléfonos: 3394949- 3394999, extensiones 2400, 2049, 2467

infocede@uniandes.edu.co

http://economia.uniandes.edu.co

Impreso en Colombia - Printed in Colombia

La serie de Documentos de Trabajo CEDE se circula con propósitos de discusión y divulgación. Los artículos no han sido evaluados por pares ni sujetos a ningún tipo de evaluación formal por parte del equipo de trabajo del CEDE.

El contenido de la presente publicación se encuentra protegido por las normas internacionales y nacionales vigentes sobre propiedad intelectual, por tanto su utilización, reproducción, comunicación pública, transformación, distribución, alquiler, préstamo público e importación, total o parcial, en todo o en parte, en formato impreso, digital o en cualquier formato conocido o por conocer, se encuentran prohibidos, y sólo serán lícitos en la medida en que se cuente con la autorización previa y expresa por escrito del autor o titular. Las limitaciones y excepciones al Derecho de Autor, sólo serán aplicables en la medida en que se den dentro de los denominados Usos Honrados (Fair use), estén previa y expresamente establecidas, no causen un grave e injustificado perjuicio a los intereses legítimos del autor o titular, y no atenten contra la normal explotación de la obra.

Universidad de los Andes | Vigilada Mineducación

Reconocimiento como Universidad: Decreto 1297 del 30 de mayo de 1964. Reconocimiento personería jurídica: Resolución 28 del 23 de febrero de 1949 Minjusticia. 


\title{
Performance, diversity and national identity \\ Evidence from association football *
}

\author{
Jorge Tovar*
}

\begin{abstract}
The increasing national diversity of co-workers has no consensus on its impact on performance. Using a team's predominant nationality as proxy for national diversity and national identity, there is robust evidence that it affects performance. Detailed workerlevel data from a highly globalized industry, association football, shows a non-linear relationship between performance and the predominant nationality of a team's roster. As the number of members from the predominant nationality increase, performance declines. However, beyond a threshold level, performance rises. It implies that performance benefits from national diversity when the predominant nationality is small and from national identity when it is large.
\end{abstract}

Keywords: National Identity, National Diversity, Team Performance

JEL codes: (M14, Z21, Z22, J15)

\footnotetext{
${ }^{*}$ An earlier version of this paper was circulated under the title Identifying positive and negative cases of the impact of coworker heterogeneity on performance. I appreciate comments at the North American Association of Sports Economist sessions held in San Diego, June 2017 as part of the Western Economic Association International conference, and participant at the European Sport Economics Association Conference (Liverpool, 2018). I also thank Veneta Andonova (Universidad de Los Andes), Federico Echenique’s (Caltech), Leo Kahane (Providence College), Sarada (University of Wisconsin), and Juan De Dios Tena (University of Liverpool) for insightful comments and suggestions. Any errors or omissions are mine.

-Associate Professor, Economics Department - Universidad de Los Andes. Email: itovar@uniandes.edu.co
} 


\title{
Desempeño, diversidad e identidad nacional: evidencia a partir del fútbol
}

\author{
Jorge Tovar
}

\begin{abstract}
A pesar del incremento en la diversidad por nacionalidad entre trabajadores, a la fecha no existe consenso sobre el impacto de este fenómeno en el desempeño de la firma. Este trabajo utiliza como proxy de identidad nacional e identidad cultural la nacionalidad predominante en un equipo para identificar de manera robusta el efecto sobre el desempeño. Para ello se utiliza información detallada del trabajador en una industria con un gran nivel de globalización como es el fútbol en Europa. Los resultados muestran una relación no lineal entre el desempeño y la nacionalidad predominante en un equipo dado. A medida que aumentan los miembros de la nacionalidad dominante en el equipo, el desempeño decae. Sin embargo, más allá de un punto, el desempeño crece. Los resultados sugieren cuando el equipo es diverso (pocos miembros de una nacionalidad mayoritaria), el desempeño se ve favorecido, pero cuando la diversidad cae, el desempeño se ve impactado por la identidad nacional.
\end{abstract}

Palabras clave: Identidad Nacional, Diversidad Nacional, Desempeño

JEL codes: (M14, Z21, Z22, J15) 


\section{Introduction}

In a world where co-workers are increasingly diverse in their nationality and skill sets (Lyons, 2017), sharing a social category, nationality for instance, matters to behavior as individuals tend to identify themselves within their social categories (Akerlof and Kranton, 2005). Social categorization generates group distinctions which can lead individuals to bolster their in-group and derogate out-groups, ultimately impacting team performance (Dahlin, Weingart, and Hinds, 2005). It is on the role of national diversity and the relevance of national identity on team performance that this paper is focused on.

Globalization has been part of the economic (and political) debate for decades, centuries, and some would say even longer. The contemporary debate dates back to the implementation of the so-called 1980s "Washington consensus," a term that denoted a firm reliance on market forces to foster economic development (Wolf, 2004). Many authors contested the supposed virtues of globalization, Rodrick (1997) among the most influential. A major critic was that the benefits of globalization, trade liberalization, in particular, had been exaggerated by its proponents.

Although it is safe to state that the consensus of the Washington Consensus has faded over time, the debate on the virtues and flaws of globalization remains an active area of research. Indeed, as the effects of globalization are questioned, the very concept of the term has expanded. It has evolved beyond the flow of goods, services, and capital underinvestment and trade agreements, as economic globalization is understood (Stiglitz, 2018), to a broader meaning which also includes the cross-border flows of information, people, and culture (Held, Goldblatt, and Perraton, 1999).

As the globalization process deepened, the rise in inequality and the divergence between "winners" and "losers" became an integral part of the discussion. ${ }^{1}$ Many, as happened in the United States with

\footnotetext{
${ }^{1}$ On the debate of globalization and inequality see for instance Maskin (2015).
} 
President Trump’s 2016 victorious campaign, claim that globalization led to the loss of jobs to workers overseas and that immigration has negatively impacted domestic welfare. ${ }^{2}$

Whether as a boost or a restraint to the economy, globalization has the potential to undermine national identity or reinforce national feelings (Ariely, 2014). Whatever the empirical effect, as national diversity rises there is an impact on how individuals see each other (Abramitzky, Boustan, and Erkisson, 2017). This is not a new phenomenon: "for as long as trade and travel have brought different races and tribes into contact with each other, human beings have asked which values we have in common" (Ignatieff, 2017). It remains true. The concerns on immigration are "as much about the social and cultural impact of immigration as the economic impact” (Manning and Roy, 2010). Indeed, some groups of people with a shared sense of mutual belonging and obligation tend to see those outside the group as different in some dimension (Earley and Mosakowski, [2000]; Dahlin, Weingart, and Hinds, [2005]; Ha and Jang, [2016]). As stated by Akerlof and Kranton (2000), it matters the identity or a person's sense of self, leading individuals to identify themselves with people in some categories while differentiating themselves from those in others.

There is no empirical consensus on the effects that national differences can have on workers' and teams' performance. That is, it is unclear whether (and eventually in which direction) the sense of belonging to the same category influences individuals and teams’ performance.

There is extensive literature linking some performance outcome to the worker's origins or their belonging to a specific group. A large strand of this literature attempts to estimate how diversity, commonly proxied by country of origin, influences performance. Some studies suggest that there is a positive effect arising from skill complementarities, enhanced problem-solving, creativity and adaptability

\footnotetext{
${ }^{2}$ Whether immigration benefits or hurts the economy has been a matter of intense research over the past decade (Peri and Sparber, [2009]; Hunt and Gauthier-Loiselle, [2010]; Collier, [2013]; Docquier, Ozden y Peri, [2014]; Borjas, [2016]; Tabellini, [2018]).
} 
(Horwitz and Hortwitz, 2007; Lazear, 2009; Stahl et al., 2010; de Jong and van Houten, 2014). Others suggest that there are adverse effects due to potential transaction costs. These costs arise due to conflicting expectations among team members, different cultural traditions, communication deficiencies associated to the use of different languages, or conflict management (Stahl et al., 2010; de Jong and van Houten, 2014; Trax, Brunow, and Suedekum, 2015). When all factors are combined, there may even be a nonlinear relation between national diversity and team performance (Earley and Mosakowski, 2000). ${ }^{3}$

Much of the empirical literature relating diversity to team performance is based on experiment, field or case studies due to the difficulties of finding the required data for a particular industry. It is "difficult, if not impossible, to get a systematic sample of the nationalities of employees on the payroll of even large international corporations” (Lazear, 1999). ${ }^{4}$ I add to the literature by exploring the link between diversity, national identity and (team and player) performance using detailed team and player-level data from two major football association football leagues. ${ }^{5}$ The empirical analysis is based on data from the Spanish and the English association football leagues, respectively known as LaLiga and the English Premier League (EPL). Beyond focusing on an economically strong globalized industry, the use of sports data is ideal for at least five reasons: (i) explicit performance data of the employer is measurable and observable; (ii) although workers differ in ability, they are relatively homogenous in other dimensions; (iii) the nationality of all workers is observable; (iv) the leagues considered are highly globalized; and (v) national identity is a particularly relevant issue in sports.

\footnotetext{
${ }^{3}$ The conflicting evidence of the impact of diversity is true also at a macro-level. Ashraf and Galor (2013) point out that diversity may increase aggregate productivity by increasing the capacity for technological advancement while diminishing it via disarray and mistrust.

${ }^{4}$ For instance, Friebel et al., (2017) relate team incentives to team performance using data from a bakery retail chain. Lyons (2017) uses a field experiment using an online contract platform. Dahlin, Weingart, and Hinds, (2005) relate team diversity and information use using students, while Earley and Mosakowski (2000) relate teams' performance and diversity in three different setups using five teams from a large multinational clothing producer, participants at an executive training course at a business school, and MBA students. Lazear (1999) has some data at the country level, and descriptive statistics for five global firms. Country level data is used in Desmet, Ortuño-Ortín, and Wacziarg (2017) and Alesina, Harnoss, and Rapoport (2016).

${ }^{5}$ Association football refers to what commonly is known as football in Europe and soccer in the United States. In this paper, I refer to it as association football, or simply football.
} 
The paper finds no role of various commonly used diversity indicator on team performance. However, understanding national identity as the sense of belonging to a given social category (nationality), allows me to explore the role that the predominant nationality in a given team has on its performance. The results robustly show that a team's and player's performance will fall as the majority group increases, but beyond a threshold, performance will benefit. The resulting U-shaped effect suggests that team performance is driven by various groups within the team when the predominant nationality is small enough, but it is influenced by the majority nationality when their number is large enough.

The results are robust to other potential self-identifying groupings. Indeed, I find an impact on performance when the majority of the team belongs to a given nationality, but not when the majority is composed of foreigners, locals or when players are bundled within potentially similar groups such as Europeans with Europeans, Africans with Africans or South Americans with South Americans.

I conclude that when the predominant nationality is small relative to other groups, team performance benefits strongly from national diversity. Similarly, when the prevailing nationality is large enough, the sense of integration that the team has around such citizenship boosts performance. National diversity and national identity strongly impact both team and individual performance. When neither is strong enough, the impact of the predominant nationality on performance is relatively weak. In short, when the prevailing nationality is either weak or dominant within a team, national diversity or national identity will drive a relatively significant impact on performance. When neither prevails, performance benefits relatively less. Overall, globalization has deepened, but cultural differences, defined by the place of origin, still mark individual and group behavior.

\section{Related Literature}

The paper relates to the literature on national identity and cultural diversity. National identity refers to the sense of inclusion that citizens from the same country feel, and how they might explicit or implicitly 
impact others. Cultural diversity refers to how a mix of individuals with different values, norms, and attitudes, perform in the workplace (Stahl et al., [2010]; Desmet, Ortuño-Ortín, and Wacziarg’s, [2017]). Culture provides a source of identity for members, mainly when they are from the same country. Cultural diversity can impact performance positively or negatively. As Lazear (1999) puts it, if the workforce had the same standards, firms would not be required to deal with diversity issues. In other words, it is the combination of workers with different languages and cultures that potentially impose a cost on the firm. Interested in the impact of internationalization on the performance of a multinational enterprise (MNE) for instance, de Jong and van Houten (2014) found a positive effect when MNE operate in culturally similar countries but negative when they do it in culturally diverse ones.

Positive effects are mostly related to the ability to exploit the potential positive externalities of having different cultures interacting within the same space. Lazear (1999) argues that workers combination of experience and problem-solving skills while interacting in the workplace, can lead to new ideas and potential gains. Trax, Brunow, and Suedukum (2015) suggest that a diverse pool of co-workers can raise productivity because of skill complementarities, or as Ashraf and Galor (2013) puts it, diversity can expand (the society's) production possibility frontier. In a meta-analysis exercise, Stahl et al., (2010) found that cultural diversity is positively associated with team satisfaction and enhanced creativity.

The potential costs of cultural diversity, on the other hand, are mostly due to transaction costs. Language differences, incompatible expectations or cultural traditions may hurt performance. Lyons (2017) concludes that when teams are nationally homogenous outcome improves while it worsens when they are nationally diverse. Stahl et al., (2010) find that cultural diversity increases task conflict and reduces social integration among members.

The empirical evidence is inconclusive, and the literature is full of mixed and conditional results. Trax, Brunow, and Suedukum (2015) do not find that a larger share of foreign workers affect productivity. 
They do see, however, evidence that given a foreign group size, the higher the number of nationalities, the stronger the impact on productivity. Horwitz and Horwitz (2007) conclude that task-related diversity, functional expertise, for instance, is positively related to team performance. Hoogendoorn and van Praag (2012) show that ethnic diversity does not affect team performance, but if at least the majority of team members are ethnically diverse, there will be some positive impact on such performance. Earley and Mosakowski (2000) find evidence of an upright U-shaped function relating team heterogeneity to team effectiveness.

Kahane, Longley and Simmons (2013) explore the impact that diversity has on team's performance using sports data, in their case from the American National Hockey League (NHL). In discussing the results, they conclude that an NHL team benefits from adding European players via two channels. There is a direct impact on performance because they are more skilled than their North American counterparts and indirectly because as more Europeans are added, they benefit from the pre-existing Europeans performance especially if they originate from the same country. Interestingly enough, though, their results also show that given an equal share of European players in a team, the team with a higher concentration (as measured by the Herfindahl-Hirschman Index -HHI-) will perform better. In other words, controlling for the share of European players; a decline in diversity will boost performance.

Kahane, Longley, and Simmons’s (2013) result that, ceteris paribus, individuals from the same country tend to boost team' performance leaves the door open to further explore their findings. As argued by them, it might be that "communications costs are always a factor when attempting to diversify: (...) language and cultural barriers may start to override any increase in diversity benefits.”

It follows that national identity may have an impact on team's performance. Relevant for our purpose, Akerlof and Kranton (2000) developed a model showing that people have identity-based payoffs derived from their own and others' actions. In a community with a non-negligible number of individuals 
from different countries (such as in LaLiga and the EPL), players from the same country identify themselves in such a way that they can impact the team's performance. In line with this hypothesis, Hochschild and Lang (2011) found, using the "national identity" module on a survey for forty-two countries, that "a strong sense of being included, frequently accompanies a desire to exclude others from one’s polity.” Related with the latter, Esteban and Rey (1994) suggest that given a set of attributes or characteristics, individuals within the same group might have a high degree of homogeneity while there might exist a high degree of heterogeneity across groups. They define such a society as a polarized one. Indeed Earley and Mosakowski (2000) conclude that moderately heterogeneous groups show a low level of team identity.

Gallo, Grund, and Reade (2013) building on the concept of oppositional identity derived by Akerlof and Kranton (2000) empirically evaluate whether referees in the EPL tend to discriminate against oppositional identical players implicitly. Exploiting the fact that the referees in their dataset were all born in the UK, they find that referees tend to book players with which they would not identify as they naturally do with white players. They do not find evidence of excess booking based on nationality issues (i.e., the UK vs. foreign).

\section{The EPL and LaLiga}

While the EPL is arguably the most worldwide known domestic association football league, LaLiga challenges this position. The former is the wealthiest league in the world, while the latter is the most successful. Together with the German Bundesliga, the Italian Calcio and the French Championnat they are known as the "big five” association football leagues (Deloitte, 2017). 
Table I

Number of players per origin in EPL and La Liga*

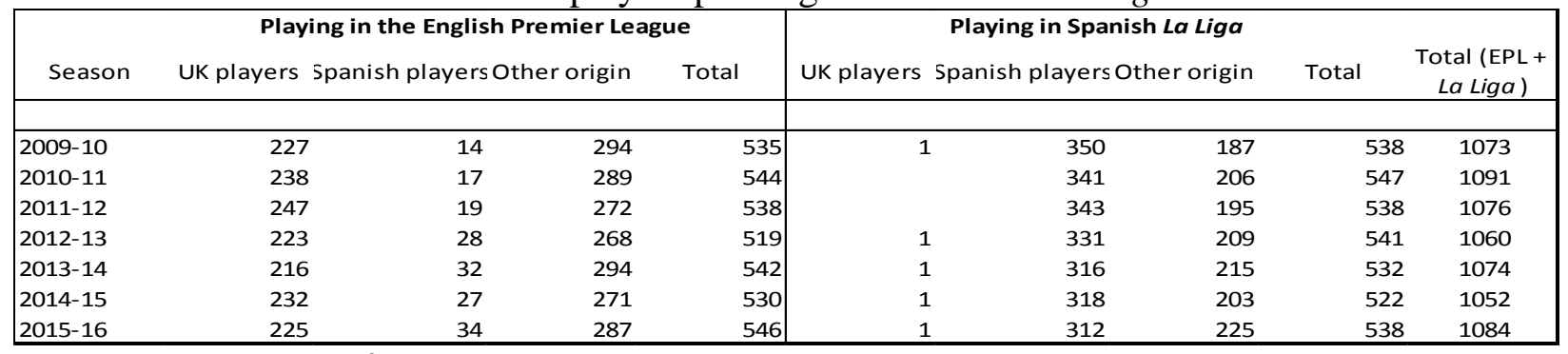

Source: whoscored.com and transfermkt.com. Own calculations.

* UK players in this table include players from England, Scotland, Wales, Northern Ireland, Gibraltar and Ireland.

Until the mid-1990s, by domestic regulation, the number of foreign players in a given squad was limited to three. The European Court of Justice ruled in 1995 that European player's rights had to be matched with those of any other fellow European citizen. What came to be known as the Bosman ruling allowed all European players to move freely across borders and work in any European Union territory. ${ }^{6}$ During the sample period considered, the EPL required a working permit for non-European citizens. To obtain such permit the player had to be either an established international for a top-50 ranked nation according to the FIFA World Ranking, or the club had to demonstrate that they were willing to pay a substantial amount in transfer fees and wages, to bring him to England. ${ }^{7}$ In Spain, each team could hire up to three non-European players. The Bosman ruling led to the surge of an entire industry seeking real or fake ancestors to deliver European passports for players around the world (Corcuera, 2014). Due to the latter, nationality is based on each player's birthplace and, as expected, the number of foreign players rose over time, leveling around 60\% and 40\% in England and Spain respectively (Table I). ${ }^{8}$

\footnotetext{
${ }^{6}$ See Frick (2009) for a complete overview of the Bosman ruling decision.

${ }^{7}$ FIFA is the world ruling body of association football.

${ }^{8}$ It could be that because a significant number of foreign players have been playing in these leagues for over two decades, then local players would be currently used to their presence and hence, the number of foreigners would not be an issue. Evidence suggests that a fully integrated environment, where differences such race, and as shown in this paper, nationality, is still to come. Recent findings suggests that in the EPL there is still some form of implicit discrimination against colored players even though they have been playing in England in significant numbers for at least three decades (See for instance Gallo, Grund, and Reade, [2013]; Palacios-Huerta, [2014] -chapter 11-; or Silberzahn and Uhlmann, [2015]).
} 
Table I, segmented per UK, Spanish and players from other origins playing in the EPL and LaLiga, shows a significant number of foreign players in each of these leagues. Over our sample period, season 2009-10 until 2015-16, players of up to 113 nationalities participated in either the EPL, LaLiga or both. To visualize the vast number of nationalities present in each league, Figure I aggregates nationalities by origin following the division reported in Table A.1. in the appendix. The EPL has a high concentration from Western Europe while Latin Americans prevail in Spain.

Figure I

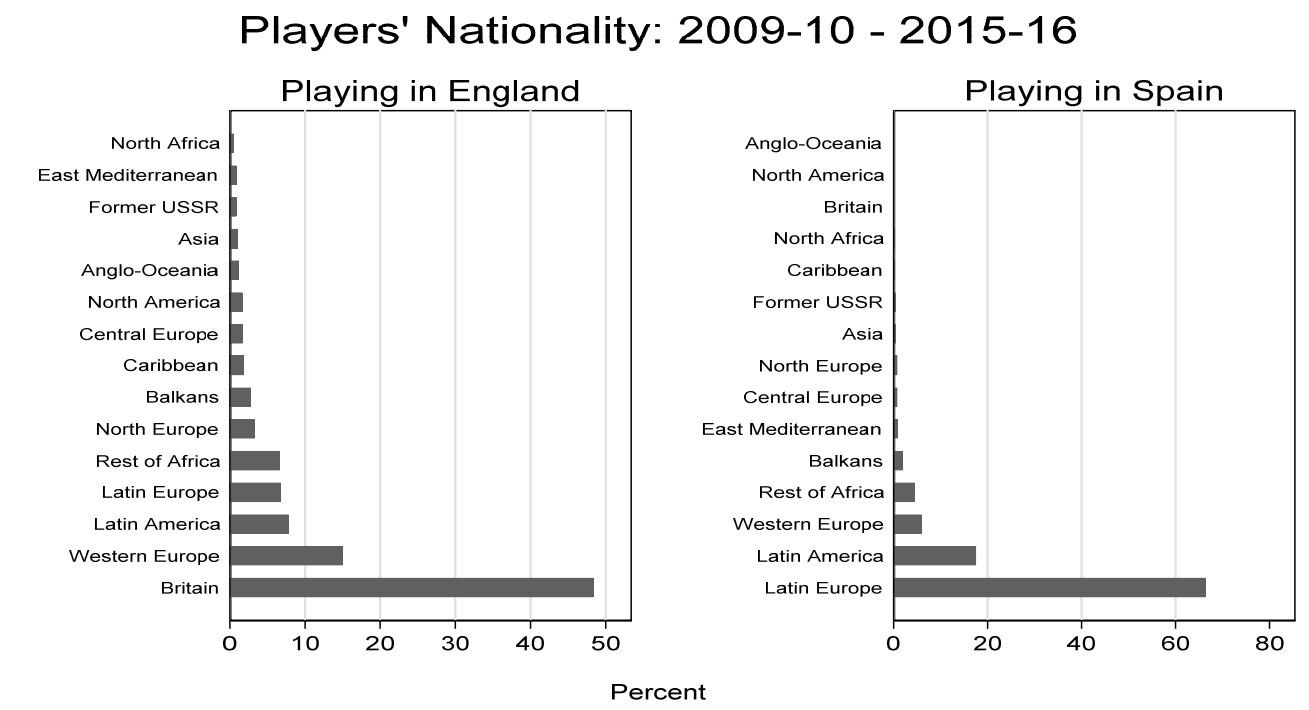

Source: Whoscored.com. Transfermkt.com. Own calculations.

\section{The Model}

The following equation relates the predominant nationality to performance:

$$
\text { Firm Performanc } e_{i t}=f\left(S_{i t}, A_{i t}, \text { Nal }_{i t}\right)
$$

where $S_{i t}$ stands for the skill level of workers in team $i$ and season $t$, and $A_{i t}$ for the managerial ability. Nalit defined below, is the variable of interest. ${ }^{9}$ In equation (1) the performance of a firm (or team) in a given

\footnotetext{
${ }^{9}$ For simplicity a league subscript (whether EPL or LaLiga) is not explicitly included in the notation.
} 
season is explained by the skills of its workers (or players), the ability of its manager (or coach) to exploit the worker's talent and the variable of interest.

The pioneering work of Rottenberg (1956) supports the underlying logic of the equation by stating that "a baseball team, like any other firm, produces its product by combining factors of production." Almost two decades later, Scully (1974) developed a production function for team performance which in time became the standard approach. ${ }^{10}$ Kahane, Longley, and Simmons (2013) base their estimates on a function as equation (1) because it determines "how diversity affects the Solow residual in a firm-level regression.”

Kahane, Longley, and Simmons (2013), like others in the literature, measure performance by the number of games won relative to the total number of games played, i.e., the percentage win. The approach is valid using data for the United States’ National Hockey League (NHL) where a draw outcome is not possible. However, draws are relatively common in association football and measuring performance just as the percentage wins implies that the number of games drawn has zero weight. Dawson, Dobson, and Gerrard (2000) recognize this and include in the percentage win indicator drawn matches as half wins, i.e. “a drawn match equals 0.5 of a win”. Such approach fails to account for the fact that during our sample period a team earns three points with a win and just one in a draw. When adjusting the percentage indicator to account for this, i.e., weighing a drawn match $1 / 3$ of a win, the percentage wins will be the same as the percentage points, another common performance indicator. Thus, choosing among these two options is irrelevant, and henceforth we will use the percentage of points won. I further calculate an additional performance indicator, the goal difference, i.e., the number of goals scored minus the number of goals allowed by each team during the season.

\footnotetext{
${ }^{10}$ It currently competes with production frontier estimations as discussed in Lee (2012). Dawson, Dobson, and Gerrard (2000) discuss in detail the strengths and limitations of a function such as equation (1)
} 
The players' skills $S$, at the team level, can be measured using some aggregation of individual performance indicators such as passes, as done in the past by Anderson and Sally (2013) and Tovar (2014) among others. Other proxies employed are aggregations of various performance measures -the Opta Index for instance (Dawson, Dobson, and Gerrard [2000])-. Teams with high-skilled players should, all else constant, perform better than teams with low-skilled ones. For the most part, however, these indicators are ex- post; hence they are simultaneously determined with the team's performance, constituting a clear estimation challenge. Moreover, current skill measures may include any performance-enhancing impact that the coach might have transmitted to the players during the season. Thus, an ex-ante measure of the players' skills is preferred (Lee, 2012).

Kahane, Longley, and Simmons (2013) deal with this by considering the players' average skills excluding the current season. The approach is valid in a US sports setup where no relegation exists. In European association football, relegation exists, i.e., the worst teams (generally between two and three) in a given season will play the following season in a lower division. Similarly, the best teams in a lower division get promoted to the next higher one. Thus, because I only have data from the top-flight divisions, the strategy followed by Kahane, Longley, and Simmons (2013) would imply a non-negligible number of teams with no data.

Note that even if such data were available, using the previous season's skill performance would ignore players' transfers across teams. It is common that a significant number of players move across teams and leagues between seasons. Players that leave from, and arrive at a given team, do not necessarily have the same skills. Consequently, averaging the players' skills from previous seasons will not necessarily capture the team's skills in the current season.

Kahane, Longley, and Simmons (2013) use other skill proxies, namely the players’ payroll, data unavailable in this dataset. Seeking for an ex-ante ability measure Dawson, Dobson and Gerrard (2000) 
used a quality index based on "predicted start-of-season transfer values (i.e., the price that a club is prepared to pay a player's current club to acquire the player's registration provided that the player is not a free agent)”. I follow this approach and use data from www.transfermkt.com, a leading online German website that regularly reports the market value of players across the world.

In the line of Dawson, Dobson, and Gerrard (2000), Herm, Callsen-Bracker, and Kreis (2014) define the market value of a player, as "the amount of money a club is willing to pay in order to make this player sign a contract, independent of an actual transaction.” This definition is appropriate because it also includes one-team players, i.e., those that have always played on the same team and, hence, have no observed market transaction fee. Transfermkt.com base their market values on the wisdom of the crowd, i.e., online members of the website aggregate each players' information provided to them. ${ }^{11}$ Herm, Callsen-Bracker, and Kreis (2014) argue and prove that the crowd-based market value closely relates to actual transfer fees, and transfer fees relate closely to player characteristics (Dawson, Dobson, and Gerrard [2000]). ${ }^{12}$ Recent work by Müller, Simons, and Weinmann (2017) implements a multilevel regression analysis to determine the market value of a player as an alternative to the wisdom of the crowd approach. Although they estimate some differences between their data-based approach and the crowd approach, these differences are small and on average tend to benefit the crowd approach.

Given the above, we proxy the teams’ skills by its market value at the beginning of the season, i.e., ex-ante. This approach guarantees that the variable is exogenous from the observed team performance in that year.

\footnotetext{
${ }^{11}$ In particular, it follows the "judge principle” whereby an empowered community member, the 'judge', reviews and adjusts if she considers it necessary the market value set by the community (Herm, Callsen-Bracker, and Kreis [2014]).

12 The crowd based approach as a mechanism to determine the market value of a given player is particularly strong when a sufficient number of members are able to provide informed arguments on the value. Transfermkt.com reports market value for players from all around the world. The accuracy of their estimates is particularly valid for the stronger leagues, including the English Premier League and LaLiga.
} 
The managerial ability, $A$, captures the coaches ability to use the player's skills to optimize team performance. To compare managerial efficiency, we use ex-ante measures as in Dawson, Dobson, and Gerrard (2000); Lee (2012); and Kahane, Longley, and Simmons (2013). We measure the coaches' experience using three proxies: the number of days spent managing a team before the current appointment, the number of points per match won during his career before his appointment and the age when appointed..$^{13}$

Each team member is assigned to a nationality according to his country of birth. The nationality with the largest number of members within a team/league/season is Nalit, the variable of interest. For instance, in Arsenal's 2009-10 roster, the dominant nationality was composed of seven foreign players, French in that case. It is not an uncommon feature of the data that the predominant nationality is composed of foreign players. I exploit the sense of mutual belonging and obligation that individuals from the same country feel when they are the majority in a given team.

Causality might be compromised if $\mathrm{Nal}_{i t}$ is not exogenous. It might be that better teams choose players from a particular nationality because they are the best. In general, selection issues might arise if a specific type of teams (traditionally dominant vs. less potent for instance) systematically focus on certain nationalities. Team fixed effects will capture time-invariant factors. However, time-variant factors might persist. To determine if such selection issues are present I follow a two-step procedure. First, I check if players from a given origin are indeed systematically better players. Second I review the relationship between teams' performance and the number of players of each nationality. The absence of the former would suggest that teams do not need to recruit players based on their nationality. Regarding the latter, if teams do not systematically sign players born in countries with relatively high-performance, I can safely move on as no selection issues would be present.

\footnotetext{
13 The experience indicator may suffer when dealing with a rookie coach. Fortunately I do not have to deal with this issue
} because there is only one rookie in the data and for simplicity I choose to ignore this sole observation. 
To meet the above goals, I need to determine each player's ability. I do so by estimating a playerlevel performance index using a principal components analysis approach (Berenger and VerdierChouchane, 2007; Tovar and Urdinola, 2014). Using the data from whoscored.com, I use available proxies for each player's performance to build a standardized performance index: goals, assists, shot per game, the percentage of successful passes, key passes, fouls, tackles, dribbling attempts, blocks, aerial duels won, ball losses, inadequate controls, and clearances. ${ }^{14}$

Figure II depicts the resulting index distribution indicating the top ten players during the sample period. Any association football fan will recognize the names of Lionel Messi (Barcelona), Cristiano Ronaldo (Real Madrid), Luis Suárez (Liverpool) and Neymar (Barcelona) as the best players around.

Figure II

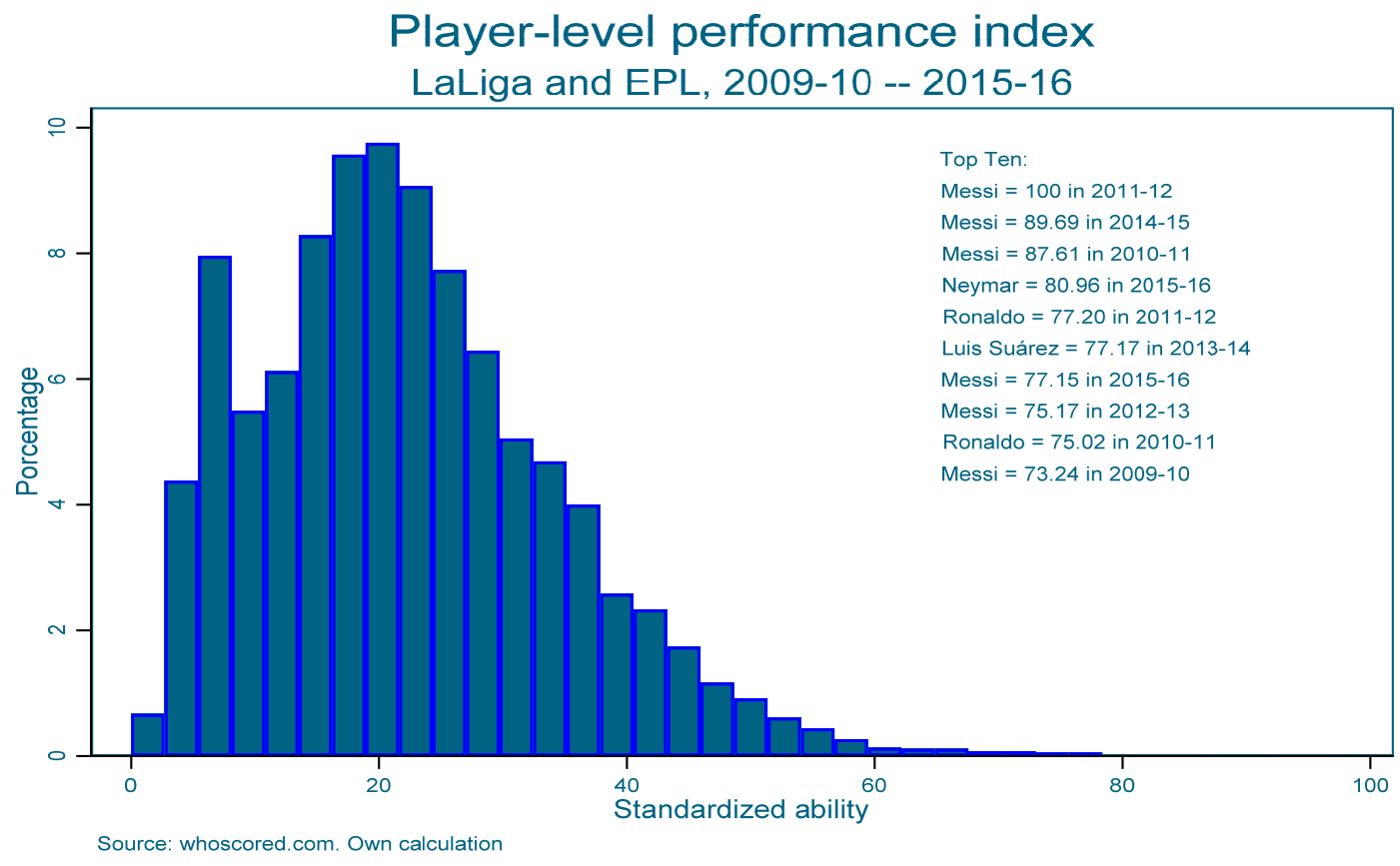

\footnotetext{
${ }^{14}$ The data reduction using the correlation matrix (as we have no categorical variable) results in five components. The choice on the number of components is largely based on the scree plot used to determine breaks between large eigenvalues and the remaining small ones. The Kaiser-Meyer-Olkin (KMO) measure of sampling adequacy and the squared multiple correlations between each variable and all other variable were estimated to determine the validity of the variables used. As in Müller, Simons, and Weinmann (2017) we exclude goalkeepers because their performance is not directly comparable with outfield players.
} 
Figure III depicts the player's average performance per nationality. On average players from Russia are the best. Note, however, that no nationality reaches an average index value of thirty, far from the values registered by top players. The best player during the sample period is on average Messi with an average index value of 81.75. Second ranks Cristiano Ronaldo (68.8). Payet (66.3), Neymar (64.3), Luis Suárez (63.8), Özil (57.6), Hazard (54.9), Mahrez (54.7), Fábregas (54.9), and De Bruyne (53.9) complete the top ten. Per country, typical football powerhouses such as Germany (24 players in the dataset and an average index of 22.7), Italy (27 players and an index of 17.6), France (90 and 27.16), England (285 and 13.3), Spain (551 and 6.9), Argentina (98 and 29.6) or Brazil (79 and 34.8) are not systematically better than players from other origins. Hence, there is no evidence that players are better based solely on their nationality.

Figure III

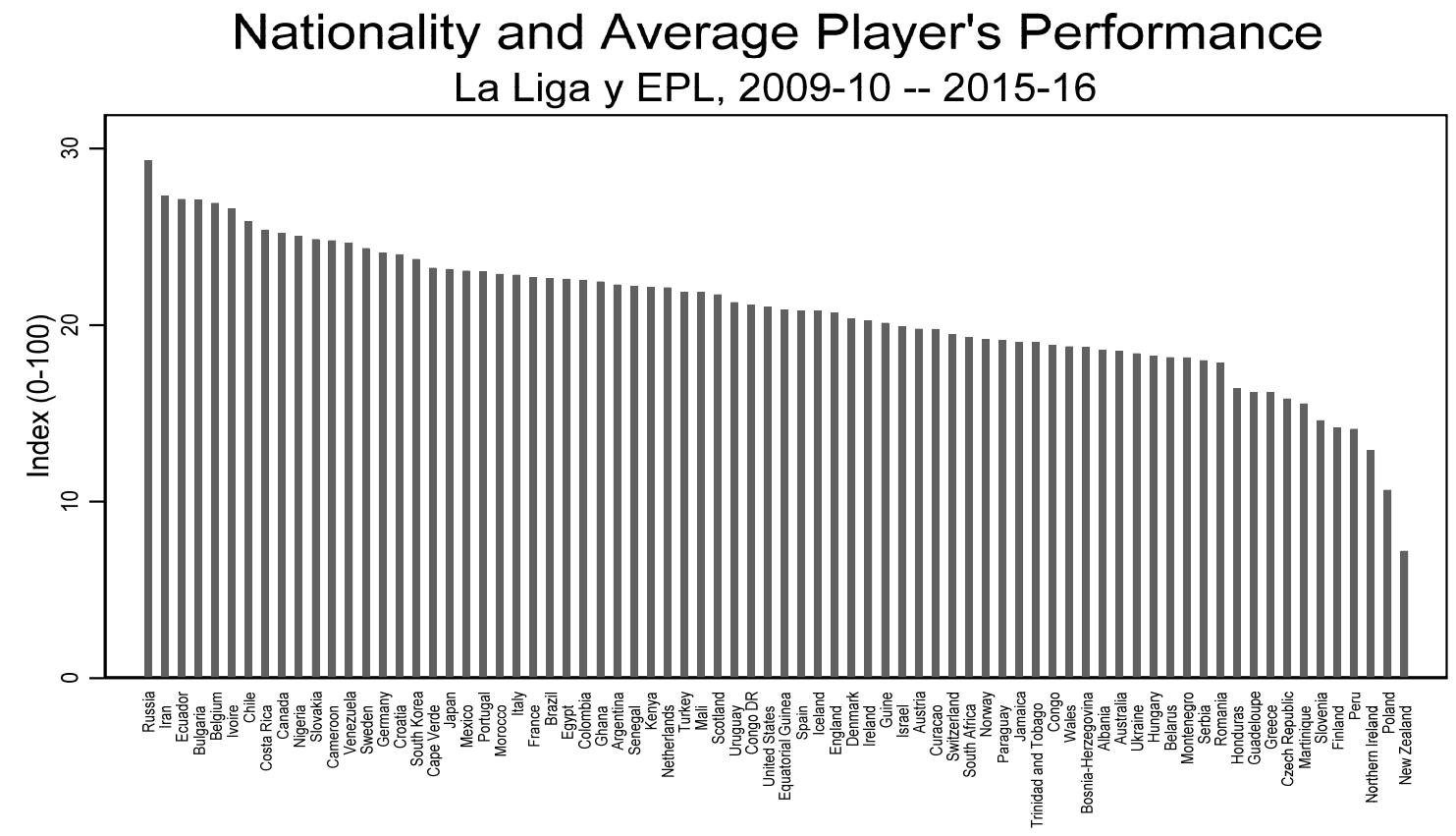

Note: The graph considers only nationalities with more than 1 player. Number of observation: 1943
Source: whoscored.com. Own Calculations

However,

the players of certain nationalities are, on average -though marginally- better than others. Thus, it is worth checking if the best teams systematically sign players from these "best" nationalities. 
Figure IV depicts the teams in the dataset sorted by their average performance over the sample period. According to the percentage of points won the best teams are Barcelona, followed by Real Madrid and Manchester United.

The horizontal axis depicts the players sorted by nationality according to Figure III's reported order. Thus, Figure IV reveals that the six Russian players (number 1 in the horizontal axis), are distributed across teams independent of their performance. Indeed, if the best teams were to select players systematically from a given nationality, there would be a horizontal dark shaded area above the value of 60 in Figure IV. Similarly, if the worst teams were to sign players from a given origin, a horizontal dark shaded area would be detected near the zero in the vertical axis. Indeed, any teams (regarding performance) signing players systematically from a given nationality would lead to a horizontal shaded dark area. There is no evidence of such a pattern. In fact, shaded regions concentrate vertically indicating that nationalities with a relative abundance of player are distributed in a relatively uniform way among the best, the worst and average teams. It is safe to conclude that there is no selection issue.

Figure IV

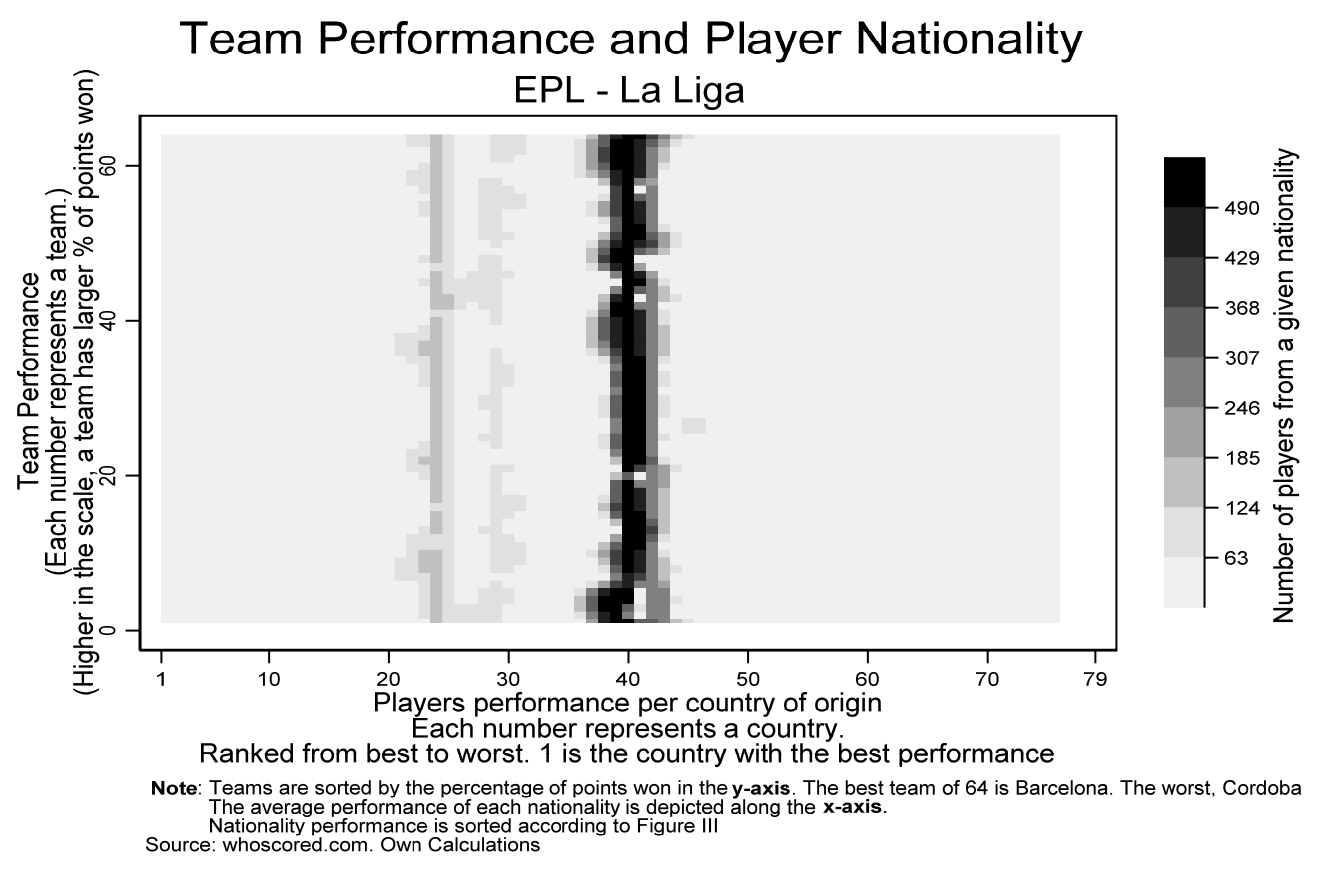


Team performance has also been linked to diversity in the literature. However, the literature has no single proxy for diversity. Arguably the most common measure is the HHI used, for instance, by Kahane, Longley, and Simmons (2013). Other proxies include the fractionalization index of the different foreign nationalities (Trax, Brunow, and Suedukum [2015]) and, taking from the biology literature, the diversity measure as developed by Jost (2006). ${ }^{15}$ The former is defined as one minus the HHI calculated only over the share of foreign workers. The latter argues that when dealing with diversity in a given environment, interest should be in the "effective number of elements" and that a diversity index should create equivalence classes among communities, i.e., "the diversity of any community reduces to the

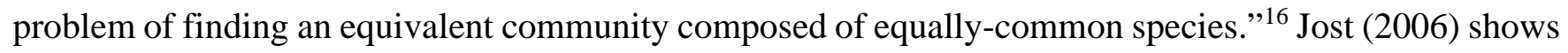
how all species (nationalities) can be weighted by their frequency, without favoring common or rare species. Jost proofs that some simple transformations over traditional concentration (or diversity measures, including the $\mathrm{HHI}$ ) are required to be able to compare different diverse communities accurately. In our particular case, we choose the transformation such that there is no favoring of either common or rare species. ${ }^{17}$

\section{The Data}

In European association football, a season typically starts in late July or early August and runs until the end of May or early June. The data spans from season 2009-10 until 2015-16. Player names in each team and season, including age; as well as teams' performance statistics are available at www.whoscored.com. These data were complemented with information on each player's nationality, date of birth and market value available at www.transfermkt.com. The latter also provides information on

\footnotetext{
${ }^{15}$ Other diversity measures, such as the derivation done in Alestina, Harnoss and Rapoport (2016), also base their estimates on the HHI.

${ }^{16}$ Jost (2006) states that "a diversity index creates equivalence classes among communities. In each of these equivalence classes there is one community whose species are all equally common”

${ }^{17}$ See Table 1 in Jost (2006).
} 
managers, including the teams managed throughout their careers, the precise spell and record in each team, as well as the date of birth.

Table II reports the summary statistics for variables included in equation (1). The average team wins $46 \%$ of games, and the predominant nationality per team has an average of 9.5 players. The mean of the HHI's is 3,019, smaller than that found in Kahane, Longley, and Simmons (2013) who, due to fewer nationalities playing hockey, report an average HHI of 5,120. Diversity, based on Jost (2006) measures reveals that an average team has over six nationalities.

Table II

Summary Statistics

\begin{tabular}{|c|c|c|c|c|}
\hline \multicolumn{5}{|l|}{ Dependent variables } \\
\hline Points won (\%) & 45.87 & 15.07 & 14.91 & 87.72 \\
\hline Goal Difference & 0.00 & 28.24 & -49.00 & 89.00 \\
\hline \multicolumn{5}{|l|}{ Variables of interest } \\
\hline $\begin{array}{l}\text { Max. Number of Players from the same } \\
\text { Country (Nal) }\end{array}$ & 9.52 & 3.96 & 2.00 & 20.00 \\
\hline $\mathrm{HHI}^{1}$ & 3040.00 & 1823.36 & 650.00 & 9050.00 \\
\hline Fractionalization index ${ }^{2}$ & 0.82 & 0.14 & 0.00 & 0.93 \\
\hline Diversity $^{3}$ & 6.11 & 2.92 & 1.22 & 16.25 \\
\hline \multicolumn{5}{|l|}{ Control variables } \\
\hline Market Value ${ }^{4}$ & 150.19 & 153.23 & 2.17 & 753.50 \\
\hline Experience $^{5}$ & 2551.44 & 1658.14 & 0.00 & 9432.00 \\
\hline Points per Match $^{6}$ & 1.57 & 0.27 & 0.00 & 2.35 \\
\hline Age Manager ${ }^{7}$ & 49.25 & 7.15 & 34.06 & 70.50 \\
\hline Matches Coached $^{8}$ & 290.02 & 218.39 & 0.00 & 1160.00 \\
\hline Number of observations & \multicolumn{4}{|c|}{280} \\
\hline $\begin{array}{l}{ }^{1} \text { Range between } 0 \text { (fully diversified) an } \\
{ }^{2} \text { Diversity rises as the index increases. } \\
{ }^{3} \text { The effective number of nationalities } i \\
{ }^{4} \text { The team's market value at the beginn } \\
{ }^{5} \text { Managers' experience (in number of da } \\
{ }^{6} \text { Managers' points per match when appc } \\
{ }^{7} \text { Managers' age when appointed. } \\
{ }^{8} \text { Number of games coached by the man }\end{array}$ & $\begin{array}{l}\text { OOO (no c } \\
\text { o diversi } \\
\text { iven tea } \\
\text { f the sea } \\
\text { when ap } \\
\text { d. }\end{array}$ & $\begin{array}{l}\text { ity) } \\
\text { all fore } \\
\text { Million o } \\
\text { ed. }\end{array}$ & $\begin{array}{l}\text { ers from th } \\
\text { uros }\end{array}$ & ame nation \\
\hline
\end{tabular}

Source: $\underline{w w w . w h o s c o r e d . c o m}$, www.transfermkt.com. Own calculations.

The average market value for a team at the beginning of the season is 150 million Euros, but as the standard deviation points out, the dispersion is significant. With only one rookie manager in our dataset, the average managers' when appointed (which may or may not be at the start of the season) is 49 
years old, has had less than seven years of experience, has achieved 1.57 points per match and has coached 290 games.

Figure V depicts the variable of interest, the majority nationality per team per league per season. It shows that its mode has seven players per team/league/season. The predominant nationality in some teams is composed of as little as two players, and in others (namely Athletic Bilbao from Spain) it can have up to $20^{18}$. Despite what one might believe a priori, the predominant nationality is not exclusively English in England and Spanish in Spain. They are majority (91\% of cases), but up to thirteen nationalities are the majority in a team/season/league in the data set.

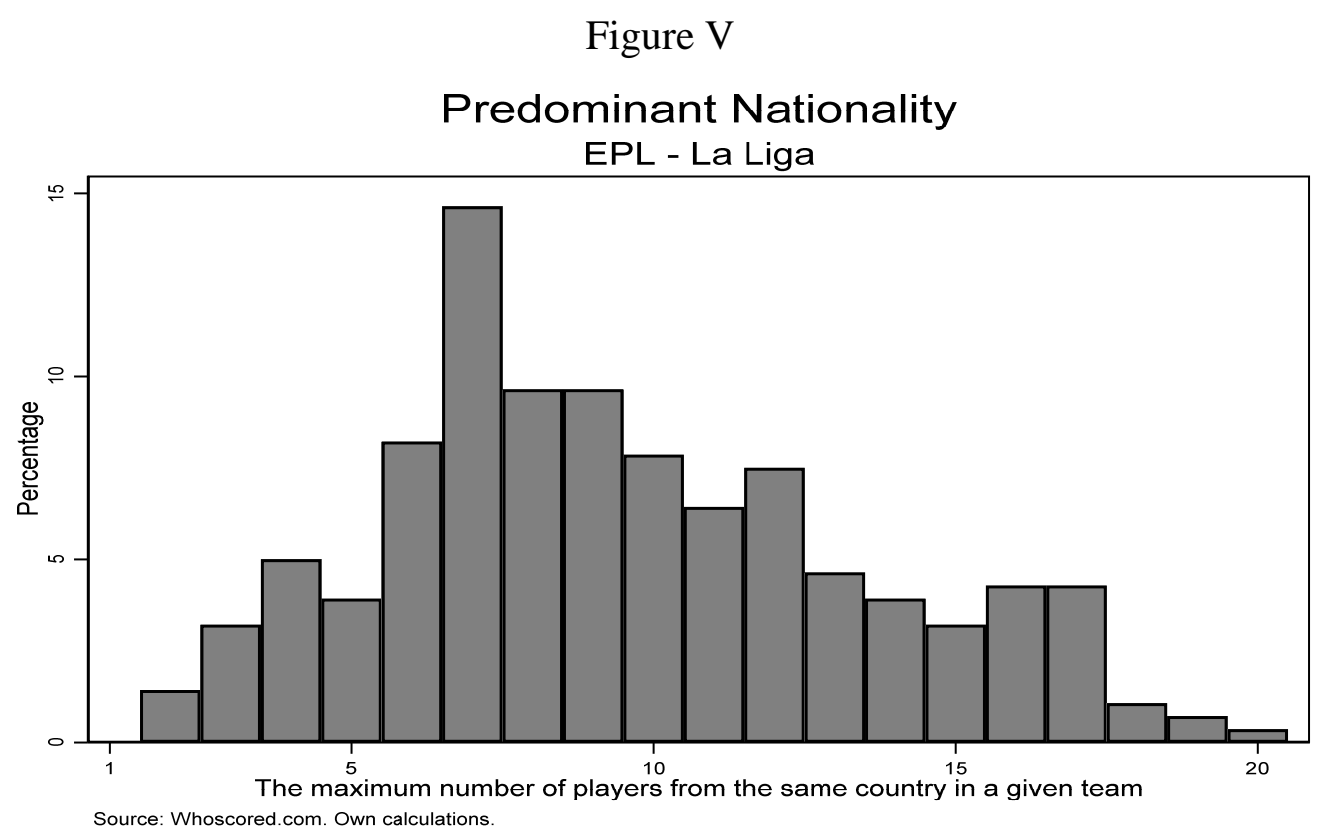

\section{Results}

Table III reports equation (1)'s results considering players that participated in at least five games during the season. The results are robust to alternative choices including just playing at least one complete game as suggested by Müller, Simons, and Weinmann (2017). The regression includes season and team

\footnotetext{
${ }^{18}$ Athletic Bilbao has historically had the policy of only hiring players born in the Basque country. Lately, however, they have relaxed such policy allowing non-native players but with Basque origins to play in the team. In fact, in each of the seven seasons available they always had at least one non-Spanish player.
} 
fixed effects, a country dummy, and the errors are robust and clustered by team to allow for intra-team correlation. The year fixed effects capture any unobservable events that might change from season to season such as the leagues' schedule and overall composition. Country fixed effects control for systematic differences between England and Spain; weather the most evident. Team fixed effects take into account the time-constant component of unobservable team-specific effects; history for instance. Consider the case of teams such as Real Madrid, Barcelona or Manchester United that carry a strong silverware history potentially able to influence performance. The Team Size controls for the team's roster size. The square of $\mathrm{Nal}$, our variable of interest, is included because there is evidence of a nonlinear relation.

The value of the team at the beginning of the season has a positive sign, but it is not statistically significant. Other common proxies used in the literature include the team value relative to the league's team value, or the normalized team value, i.e., considering the league's mean and standard deviation. The statistical insignificance remains. The result is not uncommon because much of the effect is picked up by the team fixed effect. The top teams tend to stay among the best over the years (particularly if considering seven years as done here). In general, the objective of the teams remains relatively constant over time and in part this might explain why Kahane, Longley, and Simmons (2013) find week significance in this variable.

The number of matches played as a proxy for the head coach-ability is positive and statistically significant. The negative sign of team size suggests that ceteris paribus as the group gets larger, communication problems, risk of social loafing or lower cohesion issues arise (Stahl et al., 2009).

The results suggest that performance decreases when the maximum count of players from the same country fall below a given threshold beyond which it increases. For now, we defer the detailed discussion of what the U-shape result implies. 
The results are robust whether using Goal Difference or the Percentage of Games Won as the teams' performance proxy. The former is a standard indicator in the literature, but the latter is a better proxy: one could imagine a theoretical scenario where a team wins a game by many goals, not win the rest of the games and still have a positive goal difference. In this sense, the percentage of games won looks like a stronger proxy and given that column (f) presents the specification with the best fit; I interpret the results based on it.

\section{Table III}

Team Performance and the Predominant Nationality

\begin{tabular}{|c|c|c|c|c|c|c|}
\hline & $\begin{array}{c}\text { Goal } \\
\text { Difference } \\
\text { (a) }\end{array}$ & $\begin{array}{c}\text { Goal } \\
\text { Difference } \\
\text { (b) }\end{array}$ & $\begin{array}{c}\text { Goal } \\
\text { Difference } \\
\text { (c) }\end{array}$ & $\begin{array}{l}\text { Percentage } \\
\text { of games } \\
\text { won } \\
\text { (d) }\end{array}$ & $\begin{array}{c}\text { Percentage } \\
\text { of games } \\
\text { won } \\
\text { (e) }\end{array}$ & $\begin{array}{l}\text { Percentage } \\
\text { of games } \\
\text { won } \\
\text { (f) }\end{array}$ \\
\hline Nal & $\begin{array}{c}-2.427 \\
{[0.916]^{* *}}\end{array}$ & $\begin{array}{c}-2.582 \\
{[0.928]^{* * *}}\end{array}$ & $\begin{array}{c}-1.983 \\
{[0.845]^{* *}}\end{array}$ & $\begin{array}{c}-1.643 \\
{[0.627]^{* *}}\end{array}$ & $\begin{array}{c}-1.671 \\
{[0.649]^{* *}}\end{array}$ & $\begin{array}{c}-1.402 \\
{[0.643]^{* *}}\end{array}$ \\
\hline $\mathrm{Nal}^{2}$ & $\begin{array}{c}0.099 \\
{[0.040]^{* *}}\end{array}$ & $\begin{array}{c}0.105 \\
{[0.041]^{* *}}\end{array}$ & $\begin{array}{c}0.078 \\
{[0.035]^{* *}}\end{array}$ & $\begin{array}{c}0.071 \\
{[0.028]^{* *}}\end{array}$ & $\begin{array}{c}0.071 \\
{[0.030]^{* *}}\end{array}$ & $\begin{array}{c}0.06 \\
{[0.028]^{* *}}\end{array}$ \\
\hline Team Size & $\begin{array}{c}-2.392 \\
{[0.550]^{* * *}}\end{array}$ & $\begin{array}{c}-2.4 \\
{[0.543]^{* * *}}\end{array}$ & $\begin{array}{c}-2.291 \\
{[0.568]^{* * *}}\end{array}$ & $\begin{array}{c}-1.373 \\
{[0.332]^{* * *}}\end{array}$ & $\begin{array}{c}-1.374 \\
{[0.333]^{* * *}}\end{array}$ & $\begin{array}{c}-1.322 \\
{[0.332]^{* * *}}\end{array}$ \\
\hline Teams' value at the beginning of each season & $\begin{array}{c}0.01 \\
{[0.035]} \\
\end{array}$ & $\begin{array}{c}0.013 \\
{[0.035]} \\
\end{array}$ & $\begin{array}{c}0.011 \\
{[0.034]} \\
\end{array}$ & $\begin{array}{c}0.004 \\
{[0.020]} \\
\end{array}$ & $\begin{array}{c}0.004 \\
{[0.020]} \\
\end{array}$ & $\begin{array}{c}0.004 \\
{[0.020]} \\
\end{array}$ \\
\hline Coach: Days coached when appointed & $\begin{array}{c}0.001 \\
{[0.001]}\end{array}$ & & & $\begin{array}{c}0.000 \\
{[0.000]}\end{array}$ & & \\
\hline Coach: Points per match when appointed & & $\begin{array}{l}-1.136 \\
{[4.051]}\end{array}$ & & & $\begin{array}{c}1.189 \\
{[2.681]}\end{array}$ & \\
\hline Coach: Number of matches played when appointed & & & $\begin{array}{c}0.018 \\
{[0.007]^{* * *}} \\
\end{array}$ & & & $\begin{array}{c}0.009 \\
{[0.005]^{*}} \\
\end{array}$ \\
\hline Constant & $\begin{array}{c}37.696 \\
{[11.715]^{* * *}}\end{array}$ & $\begin{array}{c}41.309 \\
{[12.728]^{* * *}}\end{array}$ & $\begin{array}{c}33.201 \\
{[12.070]^{* * *}}\end{array}$ & $\begin{array}{c}68.23 \\
{[6.592]^{* * *}} \\
\end{array}$ & $\begin{array}{c}67.079 \\
{[8.043]^{* * *}}\end{array}$ & $\begin{array}{c}65.698 \\
{[6.881]^{* * *}}\end{array}$ \\
\hline $\begin{array}{l}\text { R2 } \\
\text { Observations }\end{array}$ & $\begin{array}{l}0.87 \\
280\end{array}$ & $\begin{array}{l}0.87 \\
279\end{array}$ & $\begin{array}{c}0.88 \\
280\end{array}$ & $\begin{array}{l}0.83 \\
280\end{array}$ & $\begin{array}{l}0.83 \\
279\end{array}$ & $\begin{array}{c}0.84 \\
280\end{array}$ \\
\hline \multicolumn{7}{|c|}{$\begin{array}{l}\text { Note: Year, country and team fixed effects included in all specifications } \\
\mathrm{Nal} \text { is the number of players from the predominant nationality per team, per season. } \\
\text { Clusterd by team standard errors in brackets } \\
* \text { Significant } * 10 \%, * * 5 \%, * * * 1 \%\end{array}$} \\
\hline
\end{tabular}


The estimates for $\mathrm{Nal}$ and $\mathrm{Nal}^{2}$ are statistically significant and reveal a U-type result depicted in Figure VI. ${ }^{19}$ As Nal increases, the team performance will be hurt but only until the majority nationality reaches just over 11 players. Beyond such figure, the team performance will benefit.

The estimates reported in Table III shows that as the predominant nationality gains relative importance in the team, the cultural clash with other, by definition, minority groups affects the teams' performance negatively. However, when the leading nationality group becomes large enough, their common background propels the teams' performance. Consequently, the U-shaped effect suggests that diversity drives performance when the predominant nationality is small enough, but it is influenced by the leading majority when their number is large enough.

Our findings support the hypothesis that the predominant nationality acts as a collective community, i.e., there is a sense that having a common national identity distinguishes individuals from other groups. The sense of belonging plays a significant role and the predominant nationality, presumably with similar life experiences, schooling quality (and levels) and related value systems, tend to deal with conflict and interpret and solve problems in comparable ways (Manning and Roy, [2010]; Alesina, Harnoss, and Rapoport [2016], Ignatieff, [2017]).

\footnotetext{
${ }^{19}$ The detected non-linearity is strong. When excluding teams with $\mathrm{Nal}<5$ and $\mathrm{Nal}>15$, i.e. observations from the, both the linear and the quadratic term remain statistically significant
} 
Figure VI

The effect of the predominant nationality on team performance

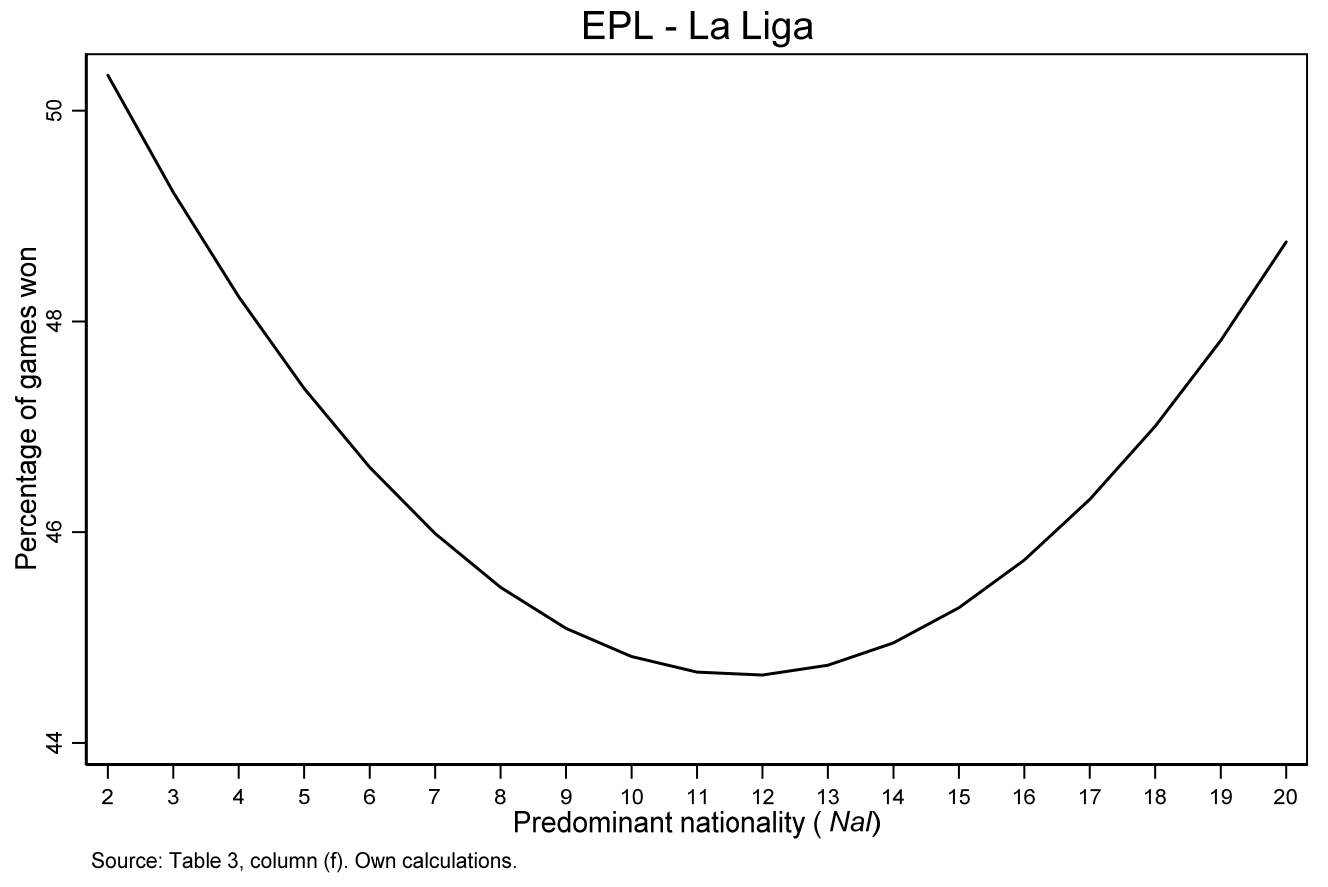

Thus far the results show that the size of the predominant nationality within a given team has an impact on the teams' performance. The claim is that diversity when the figure is small, and national identity when the figure is large is causing the effect. It might be, however, that groupings other than the predominant nationality have an impact on performance. Table IV reports estimates from equation (1) changing in each column the variable of interest $\mathrm{Nal}$ and $\mathrm{Nal}^{2}$. Specifically, Table IV replicates Table III's column (f).

Table IV reports the results for up to seven alternatives which follow the principle that a given group might influence teams’ performance. For simplicity, Table IV only reports the variable of interest. It may be that the sense of belonging of English players in England and Spanish Players in Spain impacts performance despite not being necessarily the majority group. Column (a) labeled home players, tests and found no home bias effect. Column (b) explores the possibility that foreigners, rather than nationals, 
impact performance. Again we detect no impact on performance. Columns (c) thru (e) analyze the likelihood that the number of players from culturally similar regions impact team performance. As before, there is no evidence for this. ${ }^{20}$

\section{Table IV}

Robustness checks

\begin{tabular}{|c|c|c|c|c|c|c|c|c|}
\hline & $\begin{array}{c}\text { Home } \\
\text { Players }^{1} \\
\text { (a) }\end{array}$ & $\begin{array}{c}\text { Foreigners }^{2} \\
\text { (b) }\end{array}$ & $\begin{array}{c}\text { Western } \\
\text { Europeans }^{3} \\
\text { (c) }\end{array}$ & $\begin{array}{c}\text { South } \\
\text { Americans }^{4} \\
\text { (d) }\end{array}$ & $\begin{array}{c}\text { Sub Saharan } \\
\text { Africa }^{5} \\
\text { (e) }\end{array}$ & $\begin{array}{c}\text { World } \\
\text { Champions }^{6} \\
\text { (f) }\end{array}$ & $\begin{array}{l}\text { Second } \\
\text { leading } \\
\text { group } \\
\text { (g) }\end{array}$ & $\begin{array}{c}\text { Foreigners } \\
\text { as majority } \\
\text { (h) }\end{array}$ \\
\hline Level variable & $\begin{array}{c}-0.932 \\
{[0.581]}\end{array}$ & $\begin{array}{l}-1.698 \\
{[1.857]}\end{array}$ & $\begin{array}{l}-2.224 \\
{[1.507]}\end{array}$ & $\begin{array}{c}0.24 \\
{[1.079]}\end{array}$ & $\begin{array}{c}0.243 \\
{[1.707]}\end{array}$ & $\begin{array}{l}-0.007 \\
{[0.720]}\end{array}$ & $\begin{array}{c}-0.654 \\
{[2.255]}\end{array}$ & $\begin{array}{c}35.128 \\
{[37.966]}\end{array}$ \\
\hline Squared variable & $\begin{array}{c}0.041 \\
{[0.027]}\end{array}$ & $\begin{array}{c}0.094 \\
{[0.214]}\end{array}$ & $\begin{array}{c}0.069 \\
{[0.052]}\end{array}$ & $\begin{array}{c}-0.091 \\
{[0.150]}\end{array}$ & $\begin{array}{c}0.263 \\
{[0.474]}\end{array}$ & $\begin{array}{c}0.007 \\
{[0.063]}\end{array}$ & $\begin{array}{c}-0.102 \\
{[0.324]}\end{array}$ & \\
\hline & \multicolumn{8}{|c|}{$\begin{array}{l}\text { Replicates column (f), Table 3, exchanging Nal and } \mathrm{Nal}^{2} \text {. } \\
{ }^{1} \text { Number of players from England in the EPL and Spain in LaLiga } \\
{ }^{2} \text { Number of players not from England in the EPL and not from Spain in LaLiga } \\
{ }^{3} \text { Number of players from Western Europe } \\
{ }^{4} \text { Number of players from South America } \\
{ }^{5} \text { Number of players from Sub Saharan Africa } \\
{ }^{6} \text { Number of players from countries that have been World Champions (Argentina, Brazil, } \\
\text { England, France, Germany, Italy, Spain, Uruguay) } \\
{ }^{7} \text { The number of members from the second largest nationality } \\
{ }^{8} 1 \text { if foreigners are majority. O otherwise. } \\
\text { Clustered by team standard errors in brackets. }\end{array}$} \\
\hline
\end{tabular}

Column (f) considers the possibility that players’ from countries understood in association football circles, as a familiar source of high-quality players, impact performance. Individuals from these countries might look into each other and feel that they belong to a particular category of better players. I consider the number of players from countries that have been FIFA World Champions. As prior estimations, our results are not statistically significant. ${ }^{21}$

Does the second most abundant nationality group impact performance? Column (g) shows that such group does not affect performance. Lastly, column (h) considers the possibility that foreigners, as a majority living abroad, feel some sense of integration (Hoogendoorn and van Praag, 2012). There is no

\footnotetext{
${ }^{20}$ We report the variables of interest squared following the non-linearity detected earlier. If the squared variable is excluded the results remain unaltered.

${ }^{21}$ Table IV excludes Nal and Nal2. One could argue that these variables should be kept while including the variables reported. When this is done, $\mathrm{Nal}$ and Nal2 were statistically significant following the trend found in Table III, but the variables of interest from Table IV were not statistically significant.
} 
statistically significant result. Overall, Table IV results support the hypothesis that when a group of players from the same origin is a majority, performance is affected.

Table III and Table IV combined show that when a group of countrymen is the majority, they impact performance in the way described in Figure VI. The result is valid only for such group, not for other potential groupings within the given team.

A natural question that arises from the exercise thus far relates to the relative importance that the majority group has within each team. The estimates in Table III and Table IV naturally control for the team size. However, as the number of members from the predominant nationality in a team varies, by definition diversity within it will change. When the leading nationality group is small enough, the team's diversity is larger. Similarly, when the predominant nationality consists of a large number of members, diversity is small. Therefore, I test for the potential impact that traditional diversity indicators might have on performance.

As discussed in the literature review, there is no consensus that diversity affects performance and, if it does, it can have a positive or a negative impact. Table V reports estimates based on equation (1) but, rather than using $\mathrm{Nal}_{\text {and }} \mathrm{Nal}^{2}$ it uses some measure of diversity. Column (a) uses the HHI as in Kahane, Longley, and Simmons (2013). Column (b) adds the relative share of non-Europeans as control, defined as the share of a team's players not from Europe relative to the league's average. In their paper, Kahane, Longley, and Simmons (2013) justify the inclusion of this type of variable because the HHI is, in their dataset, dominated by a particular region (North Americans in their case). Figure I reports the share of players per region of origin. Although there is no concentration as evident as that observed in the NHL, it is worth testing if these regional groups affect our estimates. ${ }^{22}$ Column (a) and column (b) in Table V show that diversity, as measured by HHI, has no impact on team performance.

\footnotetext{
${ }^{22}$ I report results for non-Europeans, but the results when using other regional classifications, namely South Americans and Latin Americans, are similar to those reported.
} 
It may be, as discussed by Jost’s (2006), that HHI is not a “true” diversity measured. Column (c) in Table V reports a non-statistically significant result. There is no apparent theoretical or empirical reason why one should include the relative share of non-Europeans as a control when estimating diversity as measured by Jost (2006). Still, for completeness, column (d) reveals that there is no impact of diversity on team performance. Column (e) and (f) use as diversity measure the fractionalization index used in Trax, Brunow, and Suedukum (2015) with similar results. ${ }^{23}$ Lastly, inspired by Trax, Brunow, and Suedukum (2015), column (g) uses the number of nationalities in the team as a proxy for diversity. Results remain unaltered.

The results show that the predominant nationality within a team has an impact on the team's performance. The next section explores the role that the predominant nationality has on individual performance.

Table V

Diversity and Performance

\begin{tabular}{|c|c|c|c|c|c|c|c|}
\hline & $\mathrm{HHI}^{1}$ & $\begin{array}{l}\text { HHI + relative } \\
\text { share of non- } \\
\text { Europeans }^{2} \\
\text { (b) }\end{array}$ & Diversity $^{3}$ & $\begin{array}{l}\text { Diversity + relative } \\
\text { share of non- } \\
\text { Europeans }{ }^{4} \\
\text { (d) }\end{array}$ & $\begin{array}{l}\text { Fractionalization } \\
\text { index }^{5} \\
\text { (e) }\end{array}$ & $\begin{array}{l}\text { Fractionalization } \\
\text { index + share of } \\
\text { foreigners per } \\
\text { team } \\
\text { (f) }\end{array}$ & $\begin{array}{c}\text { Number of } \\
\text { Nationalities }\end{array}$ \\
\hline Variable of interest & $\begin{array}{l}0.00013 \\
{[0.0006]}\end{array}$ & $\begin{array}{c}0.0005 \\
{[0.0007]}\end{array}$ & $\begin{array}{c}0.044 \\
{[0.364]}\end{array}$ & $\begin{array}{c}-0.072 \\
{[0.417]}\end{array}$ & $\begin{array}{l}-2.532 \\
{[7.132]}\end{array}$ & $\begin{array}{c}-3.952 \\
{[7.520]}\end{array}$ & $\begin{array}{l}-0.396 \\
{[0.344]}\end{array}$ \\
\hline $\begin{array}{l}\text { Additional control } \\
\text { variables }\end{array}$ & & $\begin{array}{l}1.6144 \\
{[2.441]} \\
\end{array}$ & & $\begin{array}{c}1.117 \\
{[2.403]}\end{array}$ & & $\begin{array}{c}1.156 \\
{[2.236]}\end{array}$ & \\
\hline & $\begin{array}{l}\text { Replicates } \\
{ }^{1} \mathrm{HHI} \text { by sh } \\
{ }^{2,4} \text { Relative } \\
\text { share per I } \\
{ }^{3} \text { Diversity } \\
{ }^{5} 1 \text { minus } \\
{ }^{6} \text { Share of } f \\
{ }^{7} \text { Number } \\
\text { Clustered }\end{array}$ & $\begin{array}{l}\mathrm{mn}(\mathrm{f}) \text {, Table } 3 \\
\text { f players from } \\
\text { re of non-Euro } \\
\text { e/season } \\
\text { fined by Just ( } \\
\text { efined by the } s \\
\text { gners in team } \\
\text { tionalities in a } \\
\text { am standard er }\end{array}$ & $\begin{array}{l}\text { cluding Nal } \\
\text { same natio } \\
\text { ns defined } \\
\text { 6). See text. } \\
\text { e of worker } \\
\text { h team/leag } \\
\mathrm{m} / \text { league/s } \\
\text { s in brackets } \\
\text { rmkt.com. O }\end{array}$ & $\begin{array}{l}\text { and } \mathrm{Nal}^{2} \text { and Team } \mathrm{Si} \\
\text { hality in each team/le } \\
\text { is non-Europeans sha } \\
\text { from nation } \mathrm{m} \text { amor } \\
\text { ue/season } \\
\text { eason }\end{array}$ & $\begin{array}{l}\text { eague/season } \\
\text { re per league/seas }\end{array}$ & $\begin{array}{l}\text { on/team relative to } \\
\text { rs. Trax et al. (2015) }\end{array}$ & non-European \\
\hline
\end{tabular}

${ }^{23}$ The basics of this indicator are close to that used in Alesina, Harnoss, and Rapoport (2016) and Ashraf and Galor (2013). 


\section{Individual Performance}

The results suggest that the role of the predominant nationality in a team is critical to understanding the effect on performance. However, although there is no evidence of complementarity effects by region of origin or other proxies (Table IV), the primary results (Table III) do call to explore how the dominant nationality group impacts the performance of players from other origins.

This section estimates a player-level version of equation (1) to explore the potential influence that the predominant nationality in a team might have on a player's performance. To do so, rather than team performance, it uses as the dependent variable the player-level performance index estimated earlier. This adjustment is required because neither goal difference, nor the percentage of points won is a valid performance proxy at the individual level. Kahane, Longley, and Simmons (2013), in a similar setup, used goals, points, and assists as alternative proxies. These hockey indicators are not the best choice for association football because such variables might bias the performance measures in favor of offensive players.

Table VI reports the resulting estimates, including the player's performance, lagged one season. Column (a) reports the determinants of all players' performance when the lag is available, i.e., they must exist in the dataset for at least two consecutive seasons. As expected, there is a positive correlation between the player's past performance and their current performance. The main finding is that the predominant nationality impacts the individual players' performance index similarly to that reported earlier for team performance. Column (b) explores the effect that the predominant nationality has on players from other countries. As before the effect is quadratic and statistically significant. 
Table VI

Individual Performance

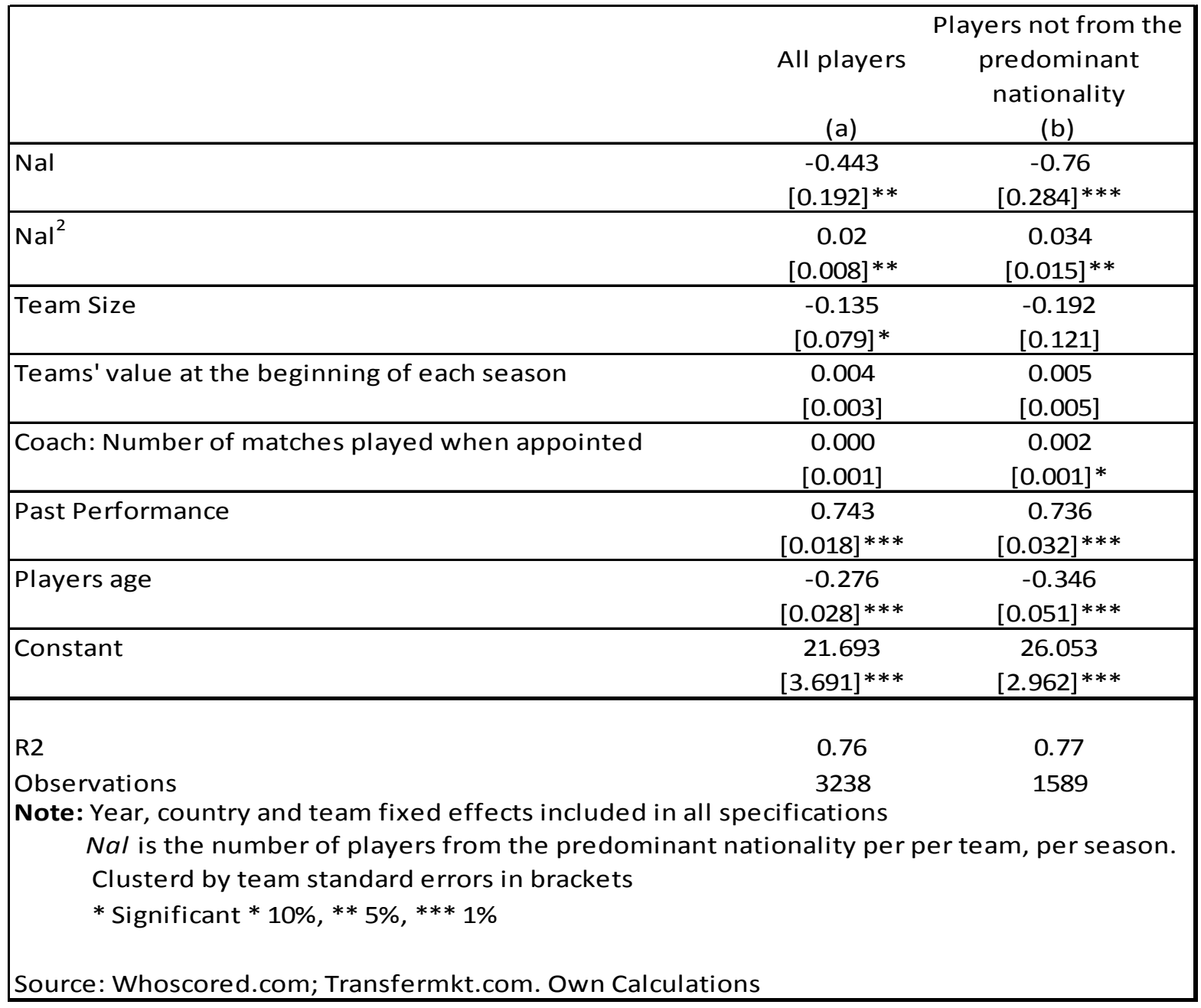

The quadratic expression found is reasonably in lines with the team findings as the minimum is achieved at a level of around eleven players from the predominant nationality. The results suggest that as the majority increase, the impact that they will have on players outside their circle will fall but only so far. The lack of leadership or absence of a collective group strong enough, as argued in the next section, is unable to boost individual performance. However, as the predominant nationality crosses the threshold (circa 11 members), the individual performance of player's from other countries will rise. 


\section{Discussion}

Andrew Carnegie believed over a century ago that economic globalization would eventually bring global peace if the "the belief system" could be integrated (Ignatieff, 2017). Time has proven that globalization can unite individuals around common beliefs, but it can also bring cultural divisions (Desmet, Ortuño-Ortín, and Wacziarg, 2017). It has led individuals from different countries, holding different nationalities, to interact and positively or negatively impact some economic or cultural outcome. Indeed, as nationality proxies for the sense of identity, members from the same country are expected to hold common cultural norms, values, and preferences. ${ }^{24}$ In turn, as individuals have a common sense of identification, the chances of social differences or categorization rises.

This paper has analyzed the role that national diversity and national identity has on team performance. In, arguably, one of the most globalized industries in the world -association football-, Carnegie's dreams have not yet been fulfilled: there is no empirical evidence of a complete integrated belief system. In other words, the sense of belonging to a given nationality has a significant impact on the aggregate performance. Diversity, as traditionally defined and used in the literature, has no significant role. Instead, it is the composition of a team regarding those who can or cannot influence the rest of team members that matters.

The main finding depicts a U-shaped relation between the predominant nationality and team (and individual) performance. The result shows that the impact is stronger when the predominant nationality is weak or strong relative to other nationalities. The former implies that many nationalities coexist in the team while the latter tends towards a single dominant nationality.

\footnotetext{
${ }^{24}$ Some authors defend that national diversity is a stronger determinant of identity than race or gender (Earley and Mokasowski, [2000]; Dahlin, Weingart, and Hinds, [2005]).
} 
The results, based on an economically relevant industry, as opposed to the particular cases commonly found in the literature, are similar to those reported in Earley and Mosakowski (2000). When the team is highly heterogeneous, i.e., when the predominant nationality is particularly small, the ability to form subgroups or self-categorize lacks strength. On the other end of the spectrum, when the team is highly homogenous, i.e., a dominant nationality is apparent, an influential group culture will develop, and the team will perform on common standards.

A straightforward explanation of the observed process is that given the absence of a strong predominant group the team benefits from diversity because their combined experience, problem-solving abilities, and skills are shared without prejudice as no group has the strength to demerit the point of view of other groups. When a team has a strong predominant nationality, the sense of self-inclusion drives the team performance.

The existing literature aids in hypothesizing the channels that explain the U-Shape relation between the predominant nationality and performance. Exploring the concept of oppositional identity, Akerloff and Kranton (2000) show that given the existence of a dominant group; a subgroup might identify with the dominant's group culture while others might not. It can be that those that try to follow the dominant group (or culture) will do so with limited success. ${ }^{25}$ Moreover, the dominant group (and those that seek to identify with their culture), will have (maybe implicitly) a sense of differentiation with those individuals that do not share their culture and values, i.e., with those that do not try to adapt to the dominant culture. Under a moderate heterogeneity scenario (when the predominant nationality has around 11 members) this will lead to a strong sense of social categorization and consequently interfere with the team's collective interests, i.e., performance will be at its lowest. The impact on team performance is at

\footnotetext{
${ }^{25}$ It does not mean that a given subgroup will change its nationality, but that it might try to adapt their behavior to the standards set by the culture of the dominant nationality.
} 
its minimum because the predominant nationality is unable to influence the rest of the team, while at the same time diversity is not enough to boost its virtues.

When teams are highly heterogeneous (a large number of nationalities) the opportunity to form strong subgroups based on national origin is minimal, and consequently, there is little chance for social categorization to have a significant impact (Earley and Mosakowski, [2000]; and Dahlin, Weingart, and Hinds, [2005]). Indeed, given a small sized predominant nationality, Earley and Mosakowski (2000) state that given the lack of social identification and self-categorization, team members "will create and establish a new shared understanding of team members’ status, team process, role expectations and communication methods.” In such a case, Lazear (1999) argues that group members can cooperate because they have complementary information and, at a sufficiently low cost, each subgroup will share and receive each other's information.

In terms of Akerlof and Kranton's (2005) model, when a team is highly homogenous (few nationalities), the impact on team performance will be substantial because most individuals in the team share the same identity, and they have little (or no) identity loss due to the lack of individuals with different identities.

In a scenario of moderate heterogeneity (near the minimum of the U-shaped curve), the virtues of diversity weaken because individuals from the same predominant nationality begin to identify between themselves socially. However, at that point their numbers are not large enough to become a robust dominant group, empirically holding back the team's performance. However, as the relative strength of the predominant nationality increases, their sense of national identity grows stronger and hence, given the channel described above, team performance will benefit. 


\section{Conclusion}

This paper has explored the role that diversity and national identity has on team and individual performance. The team's and player's performance will fall as the majority group increases. Beyond a threshold level for the leading group (11 members in the sample used), performance will increase. The resulting U-shaped effect implies that performance is driven by various groups within the team when the predominant nationality is small enough, but it is influenced by the majority when their number is large enough. The performance will benefit the least when diversity and the sense of inclusion clash with each other.

Empirically, there is no consensus on the direction of the effect that diversity can have on team performance. In an attempt to deal with this, the literature has used a variety of proxies finding either none or mixed results. Based on various types of proxies, based on the nationality structure of the teams, the paper concludes that there is no direct impact of diversity (as commonly measured) on team performance.

There is an observed impact on performance when the team is diverse regarding the number of nationalities. In such a case, national diversity boosts team performance. However, as the sense of national identity grows within the team, the benefits on performance are relatively small if neither the dominant nationality nor diversity can exercise its virtues. Lastly, when the sense of inclusion of the predominant nationality is strong enough, the entire team benefits.

A natural limitation of the framework used is that nothing is said on the potential discrimination exercised by national majorities within a team. Additional information on, for instance, the player's race or ethnicity would be required. This data is currently unavailable for me but is indeed an open line of research. 


\section{Appendix}

Just as an aggregation exercise, players were grouped according to the nationalities. Some aggregations are straightforward such as North America or Latin America. Others might deserve stronger discussions like Asia, which were aggregated based on the small number of observations available despite the apparent dissimilarities across the countries considered. Strong cultural attachments ease the classification of Latin America, the Caribbean and even the rest of Africa. Ireland is aggregated to the United Kingdom because, from an association football point of view, they are much closer than maybe in other dimensions. Similarly, France, apparently a Latin country, is included in West Europe because they seem more oriented towards the big western economies than to the other Latin European countries.

[Table A.1]

Nationalities

\begin{tabular}{|l|l|}
\hline Latin America & $\begin{array}{l}\text { Argentina, Bolivia, Brazil, Chile, Colombia, Costa Rica, Ecuador, Honduras, } \\
\text { Mexico, Panama, Paraguay, Peru, Uruguay, Venezuela }\end{array}$ \\
\hline North America & Canada, United States \\
\hline $\begin{array}{l}\text { East } \\
\text { Mediterranean }\end{array}$ & Turkey, Greece, Israel \\
\hline Balkans & $\begin{array}{l}\text { Albania, Bosnia-Herzegovina, Bulgaria, Croatia, Kosovo, Macedonia, } \\
\text { Montenegro, Serbia, Slovenia, Bulgaria }\end{array}$ \\
\hline Former USSR & Armenia, Azerbaijan, Belarus, Russia, Slovakia, Ukraine, Latvia, Lithuania \\
\hline Latin Europe & Italy, Portugal, Spain \\
\hline Central Europe & Czech Republic, Hungary, Poland, Romania \\
\hline Northern Europe & Faroe Islands, Denmark, Finland, Iceland, Norway, Sweden \\
\hline Western Europe & Austria, Belgium, France, Germany, Netherlands, Switzerland \\
\hline Northern Africa & Algeria, Egypt, Morocco, Tunisia \\
\hline Rest of Africa & $\begin{array}{l}\text { Angola, Burkina Faso, Benin, Burundi, Cameroon, Cape Verde, Chad, Congo, } \\
\text { Congo DR, Equatorial Guinea, Eritrea, Gabon, Ghana, Guinea, Guinea-Bissau, } \\
\text { Ivory Coast, Kenya, Mali, Mozambique, Nigeria, Senegal, Sierra Leone, South } \\
\text { Africa, The Gambia, Togo, Zambia, Zimbabwe }\end{array}$ \\
\hline Caribbean & $\begin{array}{l}\text { Antigua and Barbuda, Barbados, Curacao, Dominican Republic, French Guiana, } \\
\text { Grenada, Guadeloupe, Guyana, Haiti, Jamaica, Martinique, Montserrat, } \\
\text { Trinidad and Tobago }\end{array}$ \\
\hline Anglo - Oceania & Australia, New Zealand \\
\hline Asia & China, Iran, Japan, Oman, South Korea, Thailand \\
\hline Uk plus Ireland & Gibraltar, Ireland, Northern Ireland, Scotland, England, Wales \\
\hline
\end{tabular}




\section{References}

Abramitzky, R., Boustan, L., and Eriksson, K. 2017. Cultural Assimilation During the Age of Mass Migration. NBER Working Paper No. 22381.

Akerlof, G. and Kranton, R. 2000. Economics and Identity. Quarterly Journal of Economics Vol CXV (3): $715-753$.

Akerlof, G. and Kranton, R. 2005. Identity and the Economics of Organizations. Journal of Economic Perspectives. Vol. 19(1): 9-32

Alesina, A., Harnoss, J., and Rapoport, H. 2016. Birthplace Diversity and Economic Prosperity. Journal of Economic Growth. Vol. 21: 101-138.

Anderson, C. and D. Sally. 2013. The Numbers Game: Why Everything You Know about Soccer is Wrong. Penguin Books. New York.

Ariely, G., 2014. Globalization, Immigration and National Identity: How the level of globalization affects the relations between nationalism, constructive patriotism and attitudes toward immigrants? in Group Process and Intergroup Relations. Vol. 15(4): 539-557.

Ashraf, Q., and Galor, O. 2013. The “Out of Africa” Hypothesis, Human Genetic Diversity, and Comparative Economic Development. American Economic Review, 103(1): 1-46.

Berenger, V. and Verdier-Chouchane, A. 2007. Multidimensional Measures of Well-Being: Standard of Living and Quality of Life across Countries. World Development, 35(7): 1259-1276.

Borjas, G. 2016. We Wanted Workers: Unravelling the Immigration Narrative. W.W. Norton \& Company. New York.

Corcuera, J. 2014. La Ley Bosman y el Tráfico de Pasaportes. Cuadernos de Fútbol No. 61. Enero.

Dahlin, K., Weingart, L., and Hinds, P. 2005. Team Diversity and Information Use. Academy of Management Journal. Vol 48(6): 1107-1123.

Dawson, P., Dobson, S. and Gerrard, B. 2000. Estimating Coaching Efficiency in Professional Team Sports: Evidence from English Football Association. Scottish Journal of Political Economy. Vol. 47(4): 399-421.

Deloitte. 2017. Planet Football. Football Money League. Sports Business Group. January.

Desmet, K., Ortuño-Ortín, I., and Wacziarg, R. 2017. Culture, Ethnicity, and Diversity. American Economic Review Vol 107(9): 2479-2513

Collier, P. 2013. Exodus: How migration is changing our world. Oxford University Press. 
Docquier, F., Ozden, Ç, and Peri, G. 2014. The Labour Market Effects of Immigration and Emigration in OECD Countries. The Economic Journal Vol. 124 (579): 1106-1145

de Jong, G., and van Houten, J. 2014. The Impact of MNE Cultural Diversity on the Internationalizationperformance relationship. Theory and Evidence from European Multinational Enterprises. International Business Review 23: 313-326.

Earley, C., and Mosakowski, E. 2000. Creating Hybrid Team Cultures: An Empirical Test of Transnational Team Functioning. Academy of Management Journal. Vol. 43(1): 26-49.

Esteban, J. and Ray, D. 1994. On the Measurement of Polarization. Econometrica. Vol. 62(4): 819-851.

Frick, B. 2009. Globalization and Factor Mobility. The Impact of the "Bosman Ruling" on Player Migration in Professional Soccer. Journal of Sports Economics 10(1): 88-106.

Friebel, G., Heinz, M., Krueger, M., and Zubanov, N. 2017. Team Incentives and Performance: Evidence from a Retail Chain. American Economic Review. 107(8): 2168-2203.

Gallo, Edoardo, Grund, Thomas y Reade, J. James. 2013. Punishing the Foreigner: Implicit Discrimination in the Premier League Based on Oppositional Identity. Oxford Bulletin of Economics and Statistics. Vol. 75 (1), pp. 136-156.

Ha, S. and Jang, S. 2016. National Identity in a Divided Nation: South Koreans' attitudes toward North Korean defectors and the reunification of two Koreas. International Journal of Intercultural Relations Vol. 55: 109-119.

Held, D., McGrew, A., Goldblatt, D., and Perraton, J. 1999. Global Transformations. Politics, Economics and Culture. Stanford University Press.

Herm, S., Callsen-Bracker, H., and Kreis, H. 2014. When the Crowd Evaluates Soccer Players’ Market Values: Accuracy and Evaluation Attributes of an Online Community. Sport Management Review 17(4): $484-492$.

Hochschild, J., and Lang, C. 2011. Including Oneself and Including Others: Who Belongs in My Country? The Annals of the American Academy of Political and Social Science 634: 78-97.

Hoogendoorn, S., and van Praag, M. 2012. Ethnic Diversity and Team Performance: A Field Experiment. IZA Discussion Paper No. 6731.

Horwitz, S., and Horwitz, I. 2007. The Effects of Team Diversity on Team Outcomes: A Meta-Analytic Review of Team Demography. Journal of Management 33: 987-1015.

Hunt, J., and Gauthier-Loiselle, M. 2010. How Much Does Immigration Boost Innovation? American Economic Journal: Macroeconomics 2: 31-56. 
Ignatieff, M. 2017. The Ordinary Virtues. Moral Order in a Divided World. Harvard University Press. Cambridge, Massachusetts.

Jost, L. 2006. Entropy and Diversity. Oikos 113(2): 363 - 375.

Kahane, L., Longley, N. and Simmons, R. 2013. The effects of coworker heterogeneity on firm-level output: assessing the impacts of cultural and language diversity in the National Hockey League. The Review of Economics and Statistics 95(1): 302-314.

Lazear, E. 1999. Globalization and the market for teammates. Economic Journal 109, C15-C40.

Lee, Y.H. 2012. Frontier Models and their Application to the Sports Industry. The Oxford Handbook of Sports Economics Vol. 1, Kahane and Schmanske (eds): 118-134.

Lyons, E. 2017. Team Production in International Labor Markets: Experimental Evidence from the Field. American Economic Journal Applied Vol 9 (3): 70-104.

Manning, A. and Roy, S. 2010. Culture Clash or Culture Club? National Identity in Britain. Economic Journal 120 (542): F72-F100.

Masking, E. 2015. Why Haven't Global Markets Reduced Inequality in Emerging Economies? The World Bank Economic Review, Vol. 29, supplement: S48-S52.

Müller, O., Simons, A., and Weinmann, M. (2017). Beyond Crow Judgments: Data-driven Estimation of Market Value in Association Football. European Journal of Operational Research. Vol. 263 (2): 611-624.

Palacios - Huerta, Ignacio. 2014. Beautiful Game Theory: How Soccer Can Help Economics. Princeton University Press.

Peri, G. and Sparber, C. 2009. Task Specialization, Immigration, and Wages. American Economic Journal: Applied Economics 1(3): 135-169. April

Rottenberg, S. 1956. The baseball players’ labor market. Journal of Political Economy 64(3): 242-258.

Rodrick, D. 1997. Has Globalization Gone Too Far. Washington DC: Institute for International Economics.

Scully, G.W. 1974. Pay and Performance in Major League Soccer. The American Economic Review 64(6): 915-930.

Silberzahn, R. and Uhlmann, E. 2015. Many hands make tight work. Nature 526: 189-191.

Stahl, G., Maznevski, M., Voigt, A., and Jonsen, K. 2010. Unraveling the effects of cultural diversity in teams: A meta-analysis of research on multicultural work groups. Volume 41: 690-709. 
Stiglitz, J. 2018. Globalization and its Discontents. Revisited. Anti-globalization in the era of Trump. W.W. Norton \& Company, Inc. New York

Tabellini, M. 2018. Gifts of the Immigrants, Woes of the Natives: Lessons from the Age of Mass Migration. Job Market Paper http://economics.mit.edu/files/13646

Tovar, J. 2014. Gasping for Air: Soccer players’ passing behavior at high altitude. Journal of Quantitative Analysis in Sports 10(4): 411-420.

Tovar, J. and Urdinola, B. P. (2014). Inequality in National Intergenerational-Transfers: Evidence from Colombia. International Advances in Economic Research Vol. 20(2): 167-187

Trax, M., Brunow, S., and Suedukum, J. 2015. Cultural Diversity and Plant-Level Productivity. Regional Science and Urban Economics 53: 85-96.

Wolf, M. 2004. Why Globalization Works. Yale University Press. 